\title{
JAUNĀ PATĒRĒTĀJA PIRKUMA DIREKTİVA (DIREKTĪVA 2019/771): IZAICINĀJUMI UN IESPĒJAS LATVIJAS LIKUMDEVĒJAM
}

\section{NEW CONSUMER SALES DIRECTIVE (DIRECTIVE 2019/771): CHALLENGES AND POSSIBILITIES FOR LATVIAN LEGISLATOR}

\author{
Vadims Mantrovs, Dr. iur. \\ Latvijas Universitātes Juridiskās fakultātes \\ Civiltiesisko zinātṇu katedras docents
}

\section{Summary}

The present article addresses the impact of the recently adopted Consumer Sales Directive (Directive 2019/771) on Latvian consumer protection law and discusses the potential scenarios for the Latvian legislator. At the outset, the article provides a comparative overview of regulation for consumer sale of things (goods) within the framework of the new Directive and the previous Directive (Directive 1999/44/EC) by discussing the main differences of the new Directive compared with the previous Directive. This comparative analysis is conducted in conjuncture with the Consumer Rights Protection Act effective in Latvia, which transposes the norms included in the previous Directive. Furthermore, the article provides an overview of the necessary amendments, on the one hand, and possible amendments, on the other, within the framework of the new Directive. Accordingly, the article suggests several possibilities for the Latvian legislator, considering mandatory amendments to be introduced, as well as the options allowed by the new Directive itself. The article concludes with the summary of the discussion reflected in the article and suggestions for the Latvian legislator during the transposition process of the new Directive into Latvian law, namely, the Consumer Rights Protection Act.

Atslēgvārdi: Direktīva 2019/771, Direktīva 1999/44/EK, patērētājs, pirkuma līgums, lietas (preces) atbilstība ligumam, garantija

Keywords: Directive 2019/771, Directive 1999/44/EC, consumer, contract of sale, conformity of a thing (good) with the contract of sale, guarantee

\section{Ievads}

Viena no patērētāja aizsardzības tiesību formām attiecas uz patērētāja aizsardzību lietas (jeb preces patērētāju aizsardzības tiesību, tostarp Patērētāju 
tiesību aizsardzības likuma ${ }^{1}$ (turpmāk - PTAL) terminologijā̄a ${ }^{2}$ ) pirkumā, nodrošinot to, ka patērētājs iegūs tādu lietu, ${ }^{3}$ kādu viņš (-a) ir vēlējies (-usies) un kura atbilst vidusmēra patērētāja sagaidāmām lietas îpašībām, saglabājot šīs īpašỉbas noteiktā termiņā. Kā akcentēts patērētāju aizsardzības tiesību literatūrā, patērētāja pirkuma regulējumā ir vismaz paredzēts pienākums pārdevējam attiecībā uz lietas kvalitāti vai standartu, kādu varētu sagaidìt vidusmēra patērētājs, ņemot vērā to, kā pārdevējs ir raksturojis vai pārdevis lietu. ${ }^{4}$ Šāds lietas ìpašìbu minimuma standarts kontinentālās Eiropas valstīs saistìts ar vispārējo prasību patērētāja pirkumā nodrošināt lietas atbilstîbu līgumam. ${ }^{5}$

Harmonizācijas sākums ES tiesībās patērētāju aizsardzības tiesību nodrošināšanai lietas atbilstībā līgumam aizsākās ar 1999. gadu, kad tika pieñemta un spēkā stājās 1999. gada Patērētāja pirkuma direktīva (turpmāk - arī iepriekšèjā Direktīva). ${ }^{6}$ Ši Direktīva ieviesa ES tiesībās lietas atbilstỉbas līgumam jēdzienu, formulēja lietas atbilstības līgumam gadỉjumus un pieškīira patērētājam noteiktus tiesiskās aizsardzības līdzekḷus lietas neatbilstības līgumam gadỉjumā. ${ }^{7}$ Pagājušajā gadā tika pieņemta jaunā Direktīva 2019/7718 (turpmāk - 2019. gada Patērētāja pirkuma direktīva jeb jaunā Direktīva), kura aizstās iepriekš pieminēto direktīivu ar 2022. gada 1. janvāri. ${ }^{9}$ Salīdzinot ar iepriekšějo 1999. gada Patērētāja pirkuma direktīvu, jaunā Direktīva ieviesa vairākus būtiskus jauninājumus, kaut iepriekšèjās Direktīvas regulējums pēc būtības palika negrozìts. Izṇēmums no šì secinājuma attiecas uz direktīvas raksturu, ${ }^{10}$ to grozot no neizsmelošǎs direktīvas, kāda bija iepriekšējā Direktīva, ${ }^{11}$ uz izsmeḷošo direktīvu, kāda ir jaunā Direktīva. ${ }^{12}$ Kaut jaunās Direktīvas transponēšanas termiņš̌ ir 2021. gada

${ }^{1}$ Patērētāju tiesību aizsardzības likums: LV likums. Latvijas Vēstnesis, 01.04.1999., Nr. 104/105.

2 Termina "prece" legāldefinīcija sniegta PTAL 1. panta 6. punktā, un šis termins lietots citās likuma normās. Šajā rakstā atbilstoši Latvijas Republikas 1937. gada Civillikuma terminologiijai lietots termins "lieta", ņemot vērā to, ka patērētāju aizsardzības tiesības satur speciālas normas patērètāja kā speciālā subjekta aizsardzỉbai iepretim Civillikumā ietvertajām vispārīgajām normām. Tas nozīmē, ka patēerēāju aizsardzỉbas tiesību regulējumam būtu jāpamatojas uz Civillikuma terminologiju, kas arī ievērots šajā rakstā.

${ }^{3}$ Jānemem vērā, ka PTAL regulē arī pakalpojuma atbilstïbu līgumam (PTAL 14. ${ }^{1}$ pants), kas rakstā nav aplūkota. Izṇēmums ir vien gadījums, kad raksta tālākajā tekstā lietas atbilstỉbas līgumam regulējuma pilnveidošana aplūkota kopsakarā ar pakalpojuma atbilstỉbas līgumam regulējuma pilnveidošanu, ņemot vērā abu šo jautājumu ciešo saistību.

${ }^{4}$ Hawes C., Twigg-Flesner C. Sales and guarantees. In: Howells G., Ramsay I., Wilhelmsson T., Kraft D. (eds.). Handbook of Research on International Consumer Law. Cheltenham, UK; Northampton, USA: Edward Elgar Publishing, 2011, p.198.

${ }^{5}$ Ibid., p.199.

${ }^{6}$ Eiropas Parlamenta un Padomes Direktīva 1999/44/EK par dažiem patēriņa preču pārdošanas aspektiem un saistītajām garantijām. OV, L 171, 7.7.1999., 12./16. lpp. İpašais izdevums latviešu valodā: 15. nod., 4. sēj., 223.-227. lpp. [1999. gada Patēerēāja pirkuma direktīva].

7 Par šo direktivu sk., piemēram: Micklitz H.-W., Reich N., Rott P. EU consumer law. $2^{\text {nd }}$ ed. Antwerpen; Portland, Oregon: Intersentia, 2014, Chapter 4; Schulte-Nölke H. (ed.). EC Consumer Law Compendium: Comparative Analysis. Bielefeld, 2007, pp. 611-670. Available at: http://ec.europa.eu/consumers/ archive/cons_int/safe_shop/acquis/comp_analysis_en.pdf.

${ }^{8}$ Eiropas Parlamenta un Padomes Direktīva (ES) 2019/771 par atsevišķiem preču pārdošanas līgumu aspektiem, ar kuru groza Regulu (ES) 2017/2394 un Direktivu 2009/22/EK un atcel Direktîvu 1999/44/ EK. OV, L 136, 22.05.2019., 28./50. lpp. [2019. gada Patērētāja pirkuma direktīva].

9 2019. gada Patērētāja pirkuma direktīvas 23. panta pirmā rindkopa.

${ }^{10}$ Par neizsmel̦ošās un izsmeḷošās direktīvas raksturu sk. Micklitz H.-W., Reich N., Rott P. EU consumer law. $2^{\text {nd }}$ ed. Antwerpen; Portland, Oregon: Intersentia, 2014, pp. 40-42.

11 1999. gada Patērētāja pirkuma direktīvas 8. panta otrā daḷa.

12 2019. gada Patērētāja pirkuma direktĩvas 4. pants. 
1. jūlijs, ${ }^{13}$ būtiski jau pašlaik saprast, vai Latvijas pašreizējais regulējums prasa kādas izmaiṇas saistībā ar šo Direktīvu un kādas ir Latvijas likumdevēja iespējas jaunās - tagad jau izsmeḷošās - Direktīvas ietvarā. Abi šie jautājumi tiks tālāk aplūkoti atseviški.

\section{Jaunās Direktīvas raksturojums}

Kā norādīts iepriekšèjā šì raksta nodaḷā, jaunā 2019. gada Patērētāja pirkuma direktiva ir uztverama par izsmel̦ošo direktivu, kas liedz Latvijas likumdevējam grozīt šajā Direktīvā ietverto un nacionālajās tiesībās transponējamo regulējumu. Izṇēmums no šì noteiktuma pastāv tikai tad, ja šì Direktīva pati paredz iespēju paredzēt atšķirīgu regulējumu vai konkrētā jautājuma regulējums iziet ārpus Direktīvas piemērošanas jomas. ${ }^{14}$ Tāpat, kā akcentēts iepriekšèjā šî raksta nodaḷā, jaunā Direktīva pamatojas uz 1999. gada Patērētāja pirkuma direktīvas regulējumu, saturot atsevišķus papildinājumus un pilnveidojumus, bet ne pēc būtības pārgroza lietas atbilstības līgumam regulējumu, kas tika ietverts iepriekšejā Direktivā.

Jāṇem vērā, ka jaunā Direktivva ir cieši saistīta ${ }^{15}$ ar otru vienlaicīgi pieņemto Direktīvu 770/2019 saistībā ar digitāliem pakalpojumiem jeb 2019. gada Digitālo pakalpojumu direktīvu. ${ }^{16}$ 2019. gada Digitālo pakalpojumu direktīva nav šajā rakstā aplūkota ši raksta apjoma un rakstura dēl, tāpēc par tās transponēšanas jautājumiem Latvijas tiesībās nepieciešams atsevišks pētījums.

Jaunajā Direktīvā saglabāta iepriekšèjās Direktīvas piemērošanas joma. Lìdzịgi kā iepriekšèjā Direktīva, arī jaunā Direktīva attiecas uz jebkuru ${ }^{17}$ kustamu lietu' ${ }^{18}$ (jeb “preci” abu šo Direktīvu terminoloǵijā), tostarp vēl ražojamu vai izgatavojamu kustamu lietu, ${ }^{19}$ un "preci, kurai ir digitāli elementi" 20 (pēdējais lietu (preču) veids regulēts kopsakarā ar iepriekš pieminēto Direktīvu 2019/770, kura nav šajā rakstā aplūkota).

Tā kā jaunā Direktīva neparedz kardinālas izmaiṇas lietas atbilstības līgumam regulējumā, salīdzinot ar iepriekšèjo Direktīvu, nav nepieciešamības izstrādāt atsevišku likumu jaunās Direktīvas pārṇemšanai Latvijas patērētāju aizsardzības tiesībās. Tā rezultātā būtu pietiekami izdarìt izmaiṇas atseviškāās PTAL normās, lai PTAL ietvertais regulējums par lietas atbilstību līgumam un saistītajiem tiesiskās aizsardzības līdzekḷiem pārṇemtu jaunās Direktīvas normas. Tas nozīmētu izmaiṇu veikšanu PTAL III nodaḷā (lietas atbilstība lìgumam) un VII nodaḷā saistībā ar patērētājam piešķirto tiesiskās aizsardzības

13 2019. gada Patēēēāja pirkuma direktīvas 24. panta pirmā daḷa.

14 2019. gada Patērētāja pirkuma direktīvas 4. pants.

15 2019. gada Patērētāja pirkuma direktīvas 2. panta 5. punkts (sal. ar 1999. gada Patērētāja pirkuma direktīvas 1. panta otrās daļas b) punktu).

16 Eiropas Parlamenta un Padomes Direktīva (ES) 2019/770 par dažiem digitālā satura un digitālo pakalpojumu piegādes līgumu aspektiem. OV, L 136, 22.05.2019., 1./27. lpp.

17 Ar atsevišķiem izņēmumiem, kuri norādīti pašā 2019. gada Patērētāja pirkuma direktīiā (sk. šīs direktivas 2. panta 5. punktu; 3. panta ceturto un piekto daḷu) un kuri ir līdzīgi atbilstošam 1999. gada Patērētāja pirkuma direktīvas regulējumam.

18 2019. gada Patērētāja pirkuma direktīvas 3. panta pirmā daḷa kopsakarā ar 2. pantā paredzētajām terminu legāldefinīcijām (sal. ar 1999. gada Patērētāja pirkuma direktīvas 1. pantu).

19 2019. gada Patērētāja pirkuma direktīvas 3. panta otrā daḷa (atbilst 1999. gada Patērētāja pirkuma direktīvas 2. panta ceturtajai dal̦ai).

20 2019. gada Patērētāja pirkuma direktīvas 3. panta trešā daḷa. 
līdzekḷu regulējumu, kas ietverts PTAL 27.-28. pantā. Tā kā jaunā Direktīva neattiecas uz pakalpojumiem, jo tie nav uzskatāmi par "kustamu ḳermenisku lietu” (ar atsevišķiem izṇēmumiem), nav nepieciešamības izdarīt grozījumus normās, kas tieši attiecas uz pakalpojuma atbilstību līgumam, kuras regulējums iziet ārpus iepriekšèjās un jaunās Direktīvas regulējuma ietvara. Tomēr no labas likumdošanas standarta viedokḷa būtu lietderīgi apsvērt pakalpojuma atbilstības līgumam regulējuma pilnveidošanu jaunās Direktivas normu pārņemšanas gaitā, nodrošinot integrētu un savstarpēju saskanīgu regulējumu patērētāja slēgto līgumu regulējumā. ${ }^{21}$

Tāpat lietas atbilstības līgumam izpratne jaunajā Direktīvā ir palikusi negrozìta, kaut strikti nodalìti objektīvi un subjektīvi lietas atbilstības līgumam gadījumi. Šāds jaunās Direktīvas regulējums neglābjami novedīs pie nepieciešamības veikt PTAL ietvertajā regulējumā noteiktas izmaiṇas, kuras aplūkotas šì raksta apakšnodaḷā "Regulējuma struktūras izmaiṇas".

\section{Latvijas likumdevēja iespējas jaunās Direktīvas transponēšanas gaitā}

Kaut jaunā Direktīva ir izsmel̦ošā direktīva, Latvijas likumdevējam ir noteiktas iespējas reglamentēt lietas atbilstību līgumam jaunajā Direktīvā piel̦autajās rīcības brīvības robežās. Šìs iespējas skatāmas no divu skatu punktu viedokḷa: pašreizējā lietas atbilstības līgumam regulējuma struktūras izmaiņas un šì regulējuma satura izmaiņas. Katrs izmaiṇu veids tālāk šajā nodaḷa tiks aplūkots atsevišķi, sākot ar pirmo.

\section{Regulējuma struktūras izmainas}

Ieviešot jauno Direktīvu, Latvijas likumdevējam paveras nozīmīga iespēja izdarìt strukturālas izmaiṇas saistībā ar lietas atbilstības līgumam regulējumu Latvijā kopumā, novēršot esošās Latvijas Republikas 1937. gada Civillikuma (turpmāk - Civillikuma) un PTAL savstarpējās neatbilstības. Šìs neatbilstības saistītas ar to, ka kustamas lietas pirkumā (proti, iepriekšèjās un jaunās Direktīvu piemērošanas jomas ietvarā) Civillikums un PTAL paredz dažādas pieejas pārdevēja atbildībai atkarībā no tā, vai pircējs ir patērētājs.

Tā Civillikuma regulējumā atsavinātāja atbildỉba par atsavinātās lietas trūkumiem nepārsniedz gadu, ${ }^{22}$ kamēr PTAL gadijumā -2 gadus. ${ }^{23}$ Tāpat tiesiskās aizsardzības līdzekḷi pārdevēja kā atsavinātāja atbildībā Civillikumā saistīti ar pirkuma maksas samazinājumu vai līguma atcelšanu ${ }^{24}$ (neskaitot zaudējumu atlīdzības pienākumu l̦auna nolūka gadījumā ${ }^{25}$ un nokavējuma sekas, kā, piemēram, līgumsods vai nokavējuma procenti). Tai pašā laikā Civillikums tieši neparedz ${ }^{26}$ tādus tiesiskās aizsardzības lìdzekḷus saistībā ar pirkuma objekta trūkumiem, kuri pazīstami patērētāju aizsardzības tiesībās, kā pirkuma (jeb Civillikuma gadījumā - atsavinātā) objekta neatbilstības līgumam novēršana

${ }^{21}$ Sk. tālāk šĩ raksta apakšnodaḷu "Regulējuma struktūras izmaiṇas".

22 Civillikuma 1633. un 1634. pants.

23 PTAL 27. panta pirmās daḷas 1. teikums.

24 Civillikuma 1620. panta otrā daḷa.

25 Civillikuma 1620. panta pirmā daḷa.

${ }^{26}$ Kaut netieši šie tiesiskās aizsardzības līdzekḷi var izrietēt no līguma izpildes prasījuma, kurš vispārīgā veidā paredzēts Civillikuma 1590. pantā. 
(jeb pirkuma objekta remonts) vai tā apmaiṇa pret tādu objektu, kas atbilst lïgumam. ${ }^{27}$

Tai pašā laikā no mūsdienu civiltiesiskās apgrozības viedokḷa nav nepieciešams strikti nodalīt lietas atbilstības līgumam (atsavinātāja atbildības Civillikuma terminolog̣ijā) regulējumu atkarībā no tā, vai pircējs ir patērētājs. Šì atziṇa pamatojas uz apsvērumu, ka pārdevējam jāatbild par pirkuma objekta atbilstību līgumam vienādā mērā neatkarīgi no pircēja statusa, proti, vai pircējs ir uztverams par patērētāju (šo sarakstu var turpināt: vai tas ir valsts vai atsavinātā publiskā persona, komersants utt.). Tas nozīmē, ka nav nepieciešams pircējam, kurš nav patērētājs, paredzēt atšķirīgu - ìsāku - prasījuma pieteikšanas termiṇu un nabadzīgākus tiesiskās aizsardzības līdzekḷus, salīdzinot ar patērētāju, kā tas ir pašreiz Latvijā.

Tomēr modernā pieeja, kas tiek aizvien vairāk izmantota Eiropā, vairs neparedz atšķirìgu regulējumu par pirkuma objekta trūkumiem atkarībā no tā, vai pircējs ir atzīstams par patērētāju (kaut var paredzēt patērētāja pirkumam paaugstinātu aizsardzību). Atbilstoši šai pieejai pirkuma objekta trūkumu jeb lietas neatbilstības līgumam gadījumā tiek paredzēti tādi tiesiskās aizsardzības lìdzekḷi un termiņi, kuri vienlīdz attiecas uz pircēju, kurš ir patērētājs, un pircēju, kurš nav par tādu uzskatāms. Šāda pieeja tiek izmantota abās pārējās Baltijas valstīs, ${ }^{28}$ Nīderlandēe, ${ }^{29}$ Vācijā ${ }^{30}$ u. c. ES dalībvalstīs, kurās šāds regulējums ietverts šo valstu civilkodeksos (civillikumos). Vienlaikus šo valstu nacionālie normatīvie akti patērētāju aizsardzības tiesībās neparedz lietas atbilstības līgumam regulējumu, ${ }^{31}$ kas skaidrojams ar to, ka šāds regulējums ietverts šo valstu civilkodeksos (civillikumos).

Tā rezultātā jaunās Direktīvas pārņemšanas laikā Latvijas likumdevējs atradīsies izšķiršanās priekšā - saglabāt samākslotu Civillikuma un PTAL regulējuma nošķiršanu lietas atbilstībā līgumam (atsavinātāja atbildībā) vai ieviest

27 PTAL 28. panta pirmā dal̦a.

${ }^{28}$ Igaunija: Igaunijas Saistību tiesību likuma 217.-218. pants (Igaunijas Saistību tiesību likums. Pieejams anglu val.: https://www.riigiteataja.ee/en/eli/506112013011/consolide); sk.: Schulte-Nölke H. (ed.). EC Consumer Law Compendium: Comparative Analysis. Bielefeld, 2007, pp. 69-70. Available at: http:// ec.europa.eu/consumers/archive/cons_int/safe_shop/acquis/comp_analysis_en.pdf. Lietuva: Lietuvas Civilkodeksa 6.333. pants et seq, kaut patērētāju pirkumam vienlaikus paredzēts speciāls regulējums ar paaugstinātu patērētāja aizsardzību, kas noteikts Lietuvas Civilkodeksa 6.350. pantā et seq (Lietuvas Civilkodekss. Pieejams angl̦u val.: https://e-seimas.lrs.lt/portal/legalAct/lt/TAD/TAIS.245495); sk.: Schulte-Nölke H. (ed.). EC Consumer Law Compendium: Comparative Analysis. Bielefeld, 2007, p. 114. Available at: http://ec.europa.eu/consumers/archive/cons_int/safe_shop/acquis/comp_analysis_en.pdf.

29 Schulte-Nölke H. (ed.). EC Consumer Law Compendium: Comparative Analysis. Bielefeld, 2007, p. 127. Available at: http://ec.europa.eu/consumers/archive/cons_int/safe_shop/acquis/comp_analysis_en.pdf. Šāds secinājums apstiprināts arī EST praksē, kurā norādīts, ka 1999. gada Patērētāju pirkuma direktīvas normas pārṇemtas Nīderlandes Civilkodeksā (sk.: EST lieta C-497/13 Froukje Faber v. Autobedrijf Hazet Ochten BV - Faber, ECLI: EU:C:2015:357, 10. rindkopa).

30 Vācijas Civillikuma 434. pants et seq (Vācijas Civillikums. Pieejams: https://www.gesetze-im-internet. de/bgb/index.html); sk.: Schulte-Nölke H. (ed.). EC Consumer Law Compendium: Comparative Analysis. Bielefeld, 2007, p. 84. Available at: http://ec.europa.eu/consumers/archive/cons_int/safe_shop/ acquis/comp_analysis_en.pdf. Šāds secinājums apstiprināts arī EST praksēe, kurā norādīts, ka 1999. gada Patērētāju pirkuma direktīva pārṇemta, grozījumus izdarot Vācijas Civillikumā (sk.: EST lieta C-52/18 Christian Fülla v Toolport GmbH - Fülla, ECLI: EU:C:2019:447, 8. rindkopa).

${ }^{31}$ Sk., piemēram: Igaunijas Patērētāju aizsardzības likums [Consumer Protection Act]. Available at: https://www.riigiteataja.ee/en/eli/515032016002/consolide; Lietuvas Patērētāju aizsardzības likums [Law on Consumer Protection]. Available at: https://e-seimas.lrs.lt/portal/legalActPrint/lt?jfwid=18117 lifma\&documentId=e86e8310231911e6acbed8d454428fb7\&category=TAD. 
mūsdienīgu pieeju šì regulējuma vienotībā neatkarīgi no tā, vai pircējs bauda patērētāja statusu. Tipisks piemērs šādai samākslotai pieejai Latvijas tirdzniecības praksē ir pārdevēja jautājums pircējam nepārtikas preču pirkuma (piemēram, sadzīves tehnikas) gadijumā: "Vai jūs pērkat šo preci kā fiziska vai juridiska persona?” (pareizāk jau būtu jautāt, vai pirkuma objektu pērk kā patērētājs), kas nozīmē dažādu regulējuma piemērošanu lietas atbilstībā līgumam atkarībā no tā, vai pircējs ir patērētājs.

Latvijas likumdevēja izšķiršanās gadījumā par labu modernajai pieejai lietas atbilstības līgumam regulējumā ${ }^{32}$ nav saistītas ar kardinālu grozījumu veikšanu normatīvajos aktos. Šì mērķa sasniegšanai būtu nepieciešams grozìt PTAL 4. ${ }^{1}$ panta pirmo dalu, paredzot to, ka ne vien PTAL III un IV nodaḷa, bet arī PTAL 27.-28. pants attiektos arī uz pircēju, kas nav patērētājs.

Cita strukturāla rakstura izšķiršanās attiecas uz pakalpojuma atbilstību līgumam, kas tieši regulēta PTAL. ${ }^{33}$ Kaut pakalpojuma atbilstība līgumam neietilpst šì raksta tematā, jo pakalpojumi ir ārpus gan iepriekšējās, gan jaunās Direktīvas piemērošanas jomas, lietas atbilstības līgumam regulējuma pilnveidošana nevar tikt veikta atrauti no pakalpojuma atbilstības līgumam regulējuma pilnveidošanas, ņemot vērā abu šo regulējuma veidu ciešo saistību. Lìdz ar to jaunās Direktīvas pārṇemšanas laikā Latvijas likumdevējam pastāv izšķiršanās, vai šo regulējumu saglabāt, atteikties no tā vai to paplašināt. Tas jo sevišksi saistīts ar iepriekš pieminētās 2019. gada Digitālo pakalpojumu direktīvas pārṇemšanu, kas attiecas uz atsevišķu pakalpojumu - digitālo pakalpojumu - veidu (kā jau iepriekš atzīmēts, šì direktīva un tās pārņemšana nav šajā rakstā aplūkota). Būtu vien saprātīgi turpināt PTAL regulēt arī pakalpojuma atbilstību līgumam līdztekus lietas atbilstībai līgumam, kā tas ir pašreizèjā PTAL ietvertajā regulējumā. Vienlaikus varētu apsvērt, vai šo regulējumu attiecināt arī uz pircējiem, kuri nav patērētāji, no pakalpojuma atbilstības līgumam termiṇa un tiesiskās aizsardzības līdzekḷu viedokḷa. Tāpat būtu jāapsver pakalpojumu loka, uz kuru attiecas šis regulējums, paplašināšana (kā tas jau bija pirms 2014. gada) arī citiem pakalpojumu veidiem, ${ }^{34}$ nevis tikai tādiem "pakalpojumiem, kuru rezultātā tiek uzlabota vai pārveidota kustama ḳermeniska lieta vai tās īpašỉbas". ${ }^{35}$

\section{Regulējuma satura izmaiņas}

Kā jau iepriekš norādìts, 2019. gada Patērētāja pirkuma direktīva pēc būtības saglabājusi iepriekšējās Direktīvas regulējumu lietas atbilstībā līgumam, tomēr ieviesusi atsevišķas izmaiṇas. Šādu izmaiṇu esamība rada nepieciešamību Latvijas likumdevējam apsvērt grozījumu izdarīšanu PTAL, kas attiecas gan uz lietas atbilstību līgumam (PTAL III nodal̦a), gan uz termiṇiem un tiesiskās aizsardzības līdzekliem, proti, PTAL VII nodaḷā ietverto 27. pantu (terminini) un 28. pantu (tiesiskās aizsardzības līdzekḷii). Šajā situācijā jānošḳir tās izmaiṇas, kuras nepieciešams obligāti veikt PTAL jaunās Direktīvas pārṇemšanas gaitā, proti,

\footnotetext{
${ }^{32}$ Lìdzìgu secinājumu varētu izdarìt arī par citiem patēētāju aizsardzības tiesību institūtiem, kurus varētu attiecināt uz nepatērētājiem, kā tas ir izdarīts dažādās Eiropas valstīs, piemēram, iepriekš sastādīta liguma gadijumā (sk. pl.: Mantrov V. Necessity for the improvement of the regulation of standard contractual terms in Latvia. Grām.: Tiesību efektīvas piemērošanas problemātika: Latvijas Universitātes 72. zinātniskās konferences rakstu krājums. Rīga: LU Akadēmiskais apgāds, 2014, 33.-44. lpp.).

33 PTAL 14. ${ }^{1}$ pants kopsakarā ar 29. pantu.

34 Pakalpojuma veidi tieši norādīiti termina "pakalpojums" legāldefinīcijā (PTAL 1. panta 2. punkts).

35 PTAL $4 .^{1}$ panta ceturtā daḷa.
} 
obligātās izmaiṇas, no tām izmaiṇām, kuras Latvijas likumdevējs var izdarìt pēc savas izvēles. Katrs šo izmaiṇu veids tālāk tiks aplūkots atsevišksi.

No nepieciešamo izmaiṇu viedokḷa Latvijas likumdevējam būs jāizdara atsevišķas izmaiņas, galvenās no tām ir aplūkotas tālākajās šī raksta rindkopās.

Vispirms būtu jāgroza PTAL ietvertā termina "prece" legāldefinīcija, ${ }^{36}$ pārņemot jaunajā Direktīvā ietvertajā šì termina legāldefinīcijā esošo formulējumu "preces ar digitāliem elementiem". Pašlaik PTAL paredzētā šì termina legāldefinīcijā ietvertā norāde uz digitālo saturu nav pietiekama, jo ar šo norādi nav aptverti digitālie pakalpojumi, kuri izmantojami kopsakarā ar konkrēto kustamo lietu, piemēram, datoru, televizoru vai viedtālruni. Tas nenozìmē, ka būtu jāgroza visa PTAL ietvertā termina "prece" legāldefinīcija: pietiktu vien šì termina legāldefinīcijā ietverto norādi uz digitālo saturu aizstāt ar terminu "preces ar digitāliem elementiem". ${ }^{37}$ Vienlaikus lietas atbilstības līgumam regulējums PTAL 14., 27.-28. pantā būtu papildināms ar atsevišķām normām, kuras jaunā Direktīva tieši attiecina uz "precēm ar digitāliem elementiem", kā, piemēram, turpinoša digitālā pakalpojuma sniegšana. ${ }^{38}$

Tāpat jaunā Direktīva ievieš striktāku nodalījumu lietas atbilstības līgumam gadijumiem pēc to rakstura, izškirot subjektīvos un objektīvos lietas atbilstîbas līgumam gadījumus. ${ }^{39}$ Šāda pieeja neizbēgami novedīs pie grozījumu izdarīšanas PTAL 14. pantā, it sevišķi ši panta pirmajā daḷā, kurā pašlaik ietverti četri lietas atbilstības līgumam gadījumi atbilstoši iepriekšējai Direktīvai, nešķirojot tos objektīvos un subjektivos gadījumos. ${ }^{40}$

Tāpat jaunajā Direktīvā lietots termins "komercgarantija", ${ }^{41}$ kas iepriekšējai Direktīvai nav bijis pazīstams. Tomēr Eiropas patērētāju aizsardzības tiesību literatūrā šis termins ir pazīstams (kaut ne vienmēr tas literatūrā ticis atsevišķi izdalīts ${ }^{42}$ ) un ticis vērtēts kontekstā ar t. s. paplašināto garantiju. ${ }^{43}$ No komerciālās garantijas viedokḷa regulējuma jaunajā Direktīvā maz ticams, ka PTAL ietvertais garantijas regulējums ${ }^{44}$ būtu jāgroza.

Turklāt PTAL 28. pantā būtu jāiestrādā normas attiecībā uz detalizētāku regulējumu atseviš̌kiem tiesiskās aizsardzības līdzekḷiem, kuri jaunajā Direktīvā ir plašāk regulēti, kā remonts vai apmaiṇa, ${ }^{45}$ pirkuma maksas (jeb preces cenas PTAL terminologijā) samazināšana ${ }^{46}$ un pirkuma līguma atcelšana. ${ }^{47}$ Šāds

36 PTAL 1. panta 6. punkts.

37 Proti, PTAL 1. panta 6. punkta pēdējo teikumu izteikt tādā redakcijā, kāda ietverta 2019. gada Patērētāja pirkuma direktīvas 2. panta 5. punkta b) apakšpunktā.

38 2019. gada Patērētāja pirkuma direktīvas 10. panta otrā dal̦a kopsakarā ar 11. panta trešo dal̦u.

39 2019. gada Patērētāja pirkuma direktīvas 6.-7. pants. Šāds lietas atbilstības līgumam gadỉjumu iedalījums nav nekas jauns Latvijas situācijā, jo šādā veidā lietas atbilstība līgumam ilggadēji docēta Latvijas Universitātes Juridiskajā fakultātē mācību priekšmetā "Patērētāju aizsardzības tiesības".

40 1999. gada Patērētāja pirkuma direktīvas 2. panta otrā daḷa.

41 2019. gada Patērētāja pirkuma direktīvas 17. pants (sal. ar 1999. gada Patērētāja pirkuma direktīvas 6. pantu).

42 Sk., piemēram: Hawes C., Twigg-Flesner C. Sales and guarantees. In: Howells G., Ramsay I., Wilhelmsson T., Kraft D. (eds.). Handbook of Research on International Consumer Law. Cheltenham, UK; Northampton, USA: Edward Elgar Publishing, 2011, pp. 208-220.

${ }^{43}$ Micklitz H.-W., Reich N., Rott P. EU consumer law. $2^{\text {nd }}$ ed. Antwerpen; Portland, Oregon: Intersentia, 2014, Chapter 4.

44 PTAL 16. pants.

45 2019. gada Patērētāja pirkuma direktīvas 14. pants.

46 2019. gada Patēētāja pirkuma direktīvas 15. pants.

47 2019. gada Patērētāja pirkuma direktīvas 16. pants. 
plašāks regulējums neizbēgami novedīs pie atsevišḳu grozījumu izdarīšanas PTAL 28. pantā. Maz ticams tomēr, ka būtu nepieciešams šos atsevišķos tiesiskās aizsardzības līdzekḷus regulēt atsevišḳos pantos, kas var izjaukt PTAL VII nodalas struktūru.

Vēl vairāk, viens no galvenajiem jaunās Direktīvas jauninājumiem attiecas uz lietas neatbilstības lïgumam prezumpciju, kas cieši saistīta ar pierādīšanas nastas sadali lietas neatbilstības līgumam gadỉjumā. ${ }^{48}$ Ja iepriekšèjā Direktīva lietas neatbilstības līgumam prezumpciju saistīja ar sešu mēnešu termin,u, ${ }^{49}$ jaunā Direktīva to pagarina līdz vienam gadam, ${ }^{50}$ l,aujot ES dalïbvalstīm saglabāt (tām, kurām tas ir jau pašlaik paredzēts) vai ieviest divu gadu terminu. ${ }^{51}$ Pašlaik PTAL 13. panta trešā daḷa (kopsakarā ar iepriekšèjās Direktīvas 5. panta trešo daḷu) paredz: ja preces neatbilstība līguma noteikumiem atklājas sešu mēnešu laikā pēc preces iegādes, uzskatāms, ka tā eksistēja preces iegādes dienā, izṇemot gadījumu, kad šāds pieņēmums ir pretrunā ar preces raksturu vai neatbilstības veidu. Tas nozīmē, ka šajā gadījumā tieši pārdevējam, nevis patērētājam jāpierāda, ka lieta atbilda līgumam, proti, konstatējami visi PTAL 14. panta pirmajā daḷā norādītie lietas atbilstības līgumam gadījumi. Kā šajā saistībā secinājusi Eiropas Savienības Tiesa (turpmāk - EST) Faber lietā, "ja neatbilstība izpaužas tikai pēc preces piegādes datuma, iesniegt pierādījumus tam, ka šì neatbilstība izpaudās piegādes dienā, var izrādìties "nepārvarams šḳērslis patērētājam”, savukārt komersantam parasti ir daudz vieglāk pierādīt, ka neatbilstība piegādes brīdī nepastāvēja un ka tā ir radusies, piemēram, patērētājam to neatbilstoši izmantojot". 52

Ja lietas neatbilstība līgumam atklājas šo sešu mēnešu laikā no pirkuma objekta nodošanas dienas, patērētājam ir jāpierāda divi fakti: pirmkārt, pirkuma objekta neatbilstības līgumam fakts (taču ne neatbilstības cēlonis) un, otrkārt, pirkuma objekta neatbilstības līgumam rašanās fakts, atklāts sešu mēnešu laikā no šì pirkuma objekta nodošanas dienas patērētājam. ${ }^{53}$ Savukārt jaunā Direktīva, kā iepriekš norādìts, šo termiṇu un līdz ar to arī pierādīšanas nastas sadali pagarina līdz vienam gadam. Lìdz ar to Latvijas likumdevējam ir jāgroza iepriekš minētajā PTAL 13. panta trešajā daḷā ietvertais sešu mēnešu termiņš, tā vietā (kā norādìts iepriekš) nosakot vienu gadu (jaunās Direktīvas minimuma prasība) vai divus gadus (jaunās Direktīvas piedāvātā iespēja). Būtu atbilstoši, ja šajā gadijumā Latvijas likumdevējs pilnībā nodrošinātu patērētāja kā ekonomiski vājākas puses aizsardzību un paredzētu stingrāku aizsardzību, kas nozīmētu divu gadu termiṇa ieviešanu lietas neatbilstības līgumam prezumpcijā.

No iespējamo izmaiņu viedokḷa lietas atbilstības līgumam termiņš atbilstoši jaunajai Direktīvai var tikt noteikts garāks par diviem gadiem. ${ }^{54}$ Šajā situācijā Latvijas likumdevējam būtu jāapsver, vai saglabāt divu gadu termiṇu, kas

\footnotetext{
48 Par šo jautājumu Latvijas kontekstā sk.: Schewe C. Samesame but different? Consumer Sales Contracts and Burden of Proof Regarding the Damage in EU Member States. Juridiskā zinātne / Law, 2017, No. 10, pp. 104-111. Available at: https://www.journaloftheuniversityoflatvialaw.lu.lv/fileadmin/user_upload/ lu_portal/projekti/journaloftheuniversityoflatvialaw/No10/Christoph_Schewe.pdf.

49 1999. gada Patērētāja pirkuma direktīvas 5. panta trešā daḷ.

50 2019. gada Patērētāja pirkuma direktīvas 11. panta pirmā dạ̦a.

51 2019. gada Patērētāja pirkuma direktīvas 11. panta otrā daḷa

52 EST lieta C-497/13 Froukje Faber v. Autobedrijf Hazet Ochten BV - Faber, ECLI: EU:C:2015:357, 52. rindkopa.

53 Ibid., 68.-72. rindkopa.

54 2019. gada Patērētāja pirkuma direktīvas 10. panta trešā daḷa.
} 
noteikts pašlaik PTAL 27. panta pirmās daḷas pirmajā teikumā, vai to pagarināt. Jāṇem vērā, ka gan iepriekšèjās, gan jaunās Direktīvas problēma saistās ar to, ka tā neidentificē tādu lietu veidus, uz kurām šis termiņš nevar attiekties. Šis jautājums ir jau iepriekš aktualizēts Eiropas patērētāju aizsardzības tiesību literatūrā, ${ }^{55}$ taču jaunajā Direktīvā nekādas izmaiṇas saistībā ar šì termiṇa diferencēšanu dažādiem lietu veidiem nav izdarītas.

Vienlaikus Latvijas likumdevējs varētu apsvērt noilguma termiṇa ieviešanu prasījuma izlietošanai lietas neatbilstības līgumam gadījumā. Jāṇem vērā, ka gan iepriekšèjā Direktīva, ${ }^{56}$ gan jaunā Direktivva ${ }^{57}$ piel̦auj ES dalībvalstīm pakḷaut noilguma tecējumam prasījuma pieteikšanu par lietas neatbilstību līgumam. Tas saprotams tādā nozīmē, ka gadījumā, ja patērētājs divu gadu termiṇā no pirkuma objekta nodošanas dienas atklāj neatbilstību līgumam, viņš vai viṇa var pieteikt savus prasījumus tādā noilguma termiṇā, kas paredzēts nacionālajās tiesībās. Taču šì pati Direktīvas norma noteic, ka šāds noilguma termiṇš nevar notecēt pirms divu gadu prasījuma pieteikšanas termiņa notecēšanas. EST šo situāciju skaidroja Ferenschild lietā, atzīstot par šai normai neatbilstošu Beḷgíjas nacionālo normu, saskaņā ar kuru noilguma termiņš prasījuma izlietošanai lietas neatbilstības līgumam gadījumā bija viens gads, kas varēja notecēt pirms divu gadu prasījuma pieteikšanas termiṇa izbeigšanās. ${ }^{58}$ Latvijā šāds noilguma termiņš, kādā patērētājam jāpiesaka prasījums par pirkuma objekta neatbilstību līgumam, nav paredzèts, ${ }^{59}$ tāpēc patērētājs var pieteikt prasījumu par pirkuma objekta neatbilstību PTAL 27. panta pirmās daḷas pirmajā teikumā paredzētajā divu gadu prasījuma pieteikšanas termiņa laikā.

Tajā pašā laikā noilguma jautājums būtu jāaplūko kopsakarā ar prasījuma pieteikšanas termiṇu, proti, termiṇu, kādā patērētājam jāpaziṇo par konstatēto lietas neatbilstību līgumam, kas ir divi mēneši no neatbilstības atklāšanas dienas prasījuma pieteikšanas termiņa laikā. Gan iepriekšèjā, ${ }^{60}$ gan jaunā ${ }^{61}$ Direktīva paredz ES dalībvalstu iespējas ieviest šādu terminu, taču tā nav obligāta prasība. Latvijas likumdevējs ir izmantojis šì termiņa paredzēšanas iespēju. ${ }^{62}$ Saistībā ar šo termiṇu Latvijas likumdevējam būtu jāapsver, vai to saglabāt vai aizstāt ar noilguma termiņu, kas aplūkots iepriekšèjā šì raksta rindkopā. Būtu vien atbilstoši šo termiņu saglabāt, neieviešot noilguma termiņu, kas atbilstu gan vidusmēra patērētāja principam, gan pušu līdzsvara principam patērētāja pirkuma ligumā.

Tāpat Latvijas likumdevēja izšḳiršanās saistās ar to, vai divu gadu termiṇu par prasījuma pieteikšanu par lietas neatbilstību līgumam saglabāt arì attiecỉbā uz lietotām lietām vai to saīsināt līdz vienam gadam, kā to piel̦auj jaunā

\footnotetext{
55 Schulte-Nölke H. (ed.). EC Consumer Law Compendium: Comparative Analysis. Bielefeld, 2007, pp. 641-642. Available at: http://ec.europa.eu/consumers/archive/cons_int/safe_shop/acquis/comp_ analysis_en.pdf.

56 1999. gada Patērētāja pirkuma direktīvas 5. panta pirmās daḷas 2. teikums.

57 2019. gada Patērētāja pirkuma direktīvas 10. panta ceturtā daḷa.

58 EST lieta C-133/16 Christian Ferenschild v JPC Motor SA - Ferenschild, ECLI:EU:C:2017:541.

59 Sal.: PTAL 27. panta pirmo daḷu ar Ferenschild lietā EST vērtēto attiecīgo Beḷgijas nacionālo normu, kas paredzēja šādu noilguma termiņu (EST lieta C-133/16 Christian Ferenschild v JPC Motor SA Ferenschild, ECLI:EU:C:2017:541, 13. rindkopa).

60 1999. gada Patērētāja pirkuma direktīvas 5. panta otrā daḷa.

61 2019. gada Patērētāja pirkuma direktīvas 12. pants.

62 PTAL 27. panta pirmās daḷas otrais teikums.
} 
Direktīva. ${ }^{63}$ Jānnem vērā, ka līdzīga iespēja bija paredzēta iepriekšèjā Direktìvā, ${ }^{64}$ taču Latvijas likumdevējs, kā redzams no PTAL ietvertā regulējuma, to neizmantoja. ${ }^{65}$ Tas nozìmē jaunu Latvijas likumdevēja izšķiršanos, vai šādu termiṇu ieviest Latvijas patērētāju aizsardzības tiesībās attiecībā uz lietotām lietām. Ja Latvijas likumdevējs apsvērtu šāda termiṇa ieviešanu attiecībā uz lietotām lietām, būtu vienlaikus jāapsver šì termiṇa attiecināšana nevis uz visām lietotām lietām, bet uz to noteiktiem lietotu lietu veidiem, kuru gadỉjumā būtu tomēr saprātīgi šādu termiṇu paredzēt.

\section{Kopsavilkums}

Šis raksts aplūko jaunās 2019. gada Patērētāja pirkuma direktīvas (Direktīvas 771/2019) ieviestās izmaiñas lietas (jeb preces šìs Direktīvas un PTAL terminologiijā) atbilstībā līgumam kopsakarā ar PTAL ietverto regulējumu. Jaunā Direktīva pēc būtības pamatojas uz iepriekšējās 1999. gada Patērētāju pirkuma direktīvas (Direktīvas 1999/44/EK) regulējumu, taču ievieš vairākus būtiskus jauninājumus patērētāja pirkuma regulējumā. Taču šie jauninājumi būtu jāšķiro atkarībā no tā, vai tie ir obligāti pārņemami nacionālajās tiesībās vai pamatojas uz jaunajā Direktīvā tieši paredzēto nacionālā likumdevēja izvēles brīvību. Tāpēc jaunās Direktīvas ieviestās izmaiṇas būtu jāskata gan no nepieciešamo izmainu viedokḷa, kad Latvijas likumdevējam ir jāizdara grozījumi esošajā lietas atbilstības līgumam regulējumā, lai tas atbilstu jaunajai Direktīvai, gan no iespējamo izmaiṇu perspektīvas, kuru gadījumā Latvijas likumdevējs var apsvērt jaunajā Direktīvā paredzētos rīcības brīvības gadījumus.

Tā rakstā secināts, ka no nepieciešamo izmaiņu viedokḷa būtu jāpapildina termina "prece" legāldefinīcija (PTAL 1. panta 6. punkts), tajā ietverot norādi uz "precēm ar digitāliem elementiem" atbilstoši jaunajai Direktīvai. Vienlaikus lietas atbilstības līgumam regulējums PTAL 14., 27.-28. pantā būtu papildināms ar atsevišķām normām, kuras jaunā Direktīva tieši attiecina uz "precēm ar digitāliem elementiem", kā, piemēram, turpinoša digitālā pakalpojuma sniegšana. Tāpat atbilstoši jaunajai Direktīvai būtu jāizdara grozìjumi PTAL 14. pantā, ieviešot subjektīvos un objektīvos lietas atbilstības lïgumam gadijumus (četru lietas atbilstības līgumam gadījumu vietā, kā tas ir pašlaik PTAL 14. panta pirmajā daḷā atbilstoši iepriekšējai Direktīvai). Tāpat Latvijas likumdevējam būs jāgroza PTAL 13. panta trešajā dạ̣ā ietvertais sešu mēnešu termiņš lietas neatbilstības līgumam prezumpcijai, tā vietā nosakot viena gada termiṇu, kas ir jaunajā Direktīvā paredzētais minimālais termiņš̌, vai divus gadus, kas ir šajā Direktīvā paredzētā izvēles iespēja. Kā rakstā secināts, būtu ieteicams ieviest divu gadu termiņu saistībā ar lietas neatbilstības līgumam prezumpciju.

Vienlaikus no iespējamo izmaiṇu viedokḷa būtu ieteicams saglabāt divu gadu termiņu lietas atbilstībai līgumam, kas noteikts pašlaik PTAL 27. panta pirmās dal̦as pirmajā teikumā, nevis to pagarināt, kā to tieši piẹ̦auj jaunā Direktīva. Būtu arī mērḳtiecīgi nesaīsināt šo termiṇu lietotu lietu gadījumā, kā tas ir pašlaik spēkā esošajā PTAL regulējumā. Tāpat būtu ieteicams saglabāt divu mēnešu lietas neatbilstības līgumam atklāšanas termiṇu, neaizstājot to ar noilgumu, kā

${ }^{63}$ 2019. gada Patērētāja pirkuma direktīivas 10. panta sestā daḷa.

64 1999. gada Patērētāja pirkuma direktīvas 7. panta pirmās daḷas otrā rindkopa.

${ }^{65}$ Sk. ippaši PTAL 27. pantu, kurā ievietoti termiṇi lietas atbilstỉbas līgumam regulējuma ietvaros. 
tas ir pašreizējā PTAL regulējumā, kas atbilstu gan vidusmēra patērētāja principam, gan pušu līdzsvara principam patērētāja pirkuma līgumā.

Tomēr iepriekš raksturoto izmaiņu izdarīšana PTAL jāveic kopsakarā ar lietas atbilstības līgumam regulējuma strukturālām izmaiṇām, novēršot samākslotu šì regulējuma nošķiršanu Civillikumā un PTAL atkarībā no tā, vai pircējs ir patērētājs. Tāpēc rakstā izvirzìts un pamatots priekšlikums sekot modernajām tendencēm Eiropā un ieviest tādus tiesiskās aizsardzības līdzekḷus un terminus par pirkuma objekta (vai pakalpojuma) trūkumiem, kuri attieksies uz jebkuru kustamas lietas pirkumu neatkarīgi no tā, vai pircējs ir vai nav patērētājs. Šì mērḳa sasniegšanai būtu nepieciešams grozìt PTAL $4 .^{1}$ panta pirmo dal̦u, paredzot to, ka ne vien PTAL III un IV nodal̦a, bet arī PTAL 27.-28. pants attiektos arī uz pircēju, kas nav patērētājs. Tāpat būtu vien saprātīgi turpināt PTAL regulēt arī pakalpojuma atbilstību līgumam lìdztekus lietas atbilstībai līgumam, kā tas ir pašreizējā PTAL ietvertajā regulējumā. Vienlaikus varētu apsvērt, vai šo regulējumu attiecināt arī uz pakalpojuma saṇēmējiem, kuri nav patērētāji, no pakalpojuma atbilstības līgumam termina un tiesiskās aizsardzības lìdzekḷu viedokḷ. Tāpat būtu jāapsver atgriezties pie pakalpojumu loka paplašināšanas arī uz citiem pakalpojumu veidiem, nevis tikai uz tādiem "pakalpojumiem, kuru rezultātā tiek uzlabota vai pārveidota kustama ķermeniska lieta vai tās īpašỉbas". 